\title{
一特菜一。 \\ フライトシミュレーション技術とその応用*1
}

松島弘 一*2

Key Words : Flight Simulation, Flight Simulator, In-Flight Simulator

\section{1.はじめに}

“フライトシミュレーション”の意味するところを 「ある飛行事象の時間経過にともなうなりゆきを、数 学的モデル，あるいは物理的モデルを通して実現させ る」と広く考えることにすると，航空宇宙分野の研究 開発において用いられているアプローチの大半を内包 することになる，すなわち，計算機をはじめとするエ レクトロニクスの目ざましい発達は，航空宇宙の分野 における研究や開発の作業に実に多様な手法を提供し ているが，そのほとんどは何らかの意味で“シミニレ ーション”という言葉で呼ばれているものである.し かしここで考えようとしているのは“シミニレータ” という言莱を聞いたときに普通多くの人が連想する， 計算機と模擬コックピットを結びつけた，いわゅる "フライトシミュレータ"，あるいは実際の航空機をべ ースにした“インフライトシミュレータ”によるシミ ュレーションが. HOPE をはじめとする将来の宇宙 往摆機の開発で、どのような役割を演じることができ るかという問題である。そのためにまずフライトシミ ムレーションを広義にとらえたとき，本稿で考えよう としている“シミュレーション”がどのような位置付 けになるかを明確にし，その上で現実に“フライトシ ミュレータ”あるいは“インフライトシミュレータ” をどう活用するかを具体的に述へることにする．

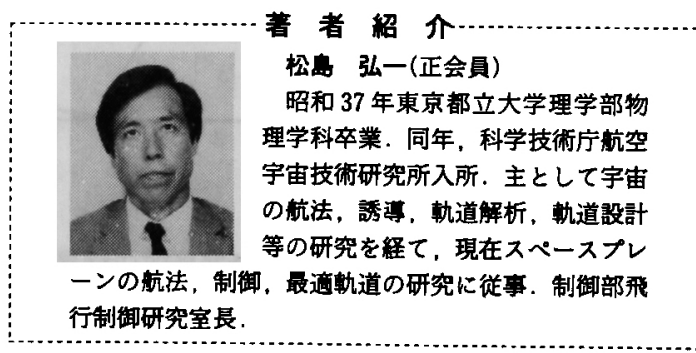

\footnotetext{
*1 平成元年 10 月 18 日, 第 27 回飛行機シンポシウムにて請 演. 平成 2 年 7 月 27 日原稿受理 Flight Simulation and Its Application

*2 航空宇宙技術研究所 Koichi MATSUSHIMA
}

\section{2. フライトシミュレーションについて}

フライトシミュレーションを改めて図示すると第 1 図のようになるが1).シミュレーションと呼ばれるも のは，基本的には模擬しょうとする事象を忠実に実現 させることであり．したがってそのために最も適した 手段を選ぶことが常に重要な課題である。しかし忠実 な模擬事象の実現といってもその形態は一様ではな く，シミュレーションを行う目的によって実に様々な ものが考えられる.実はこのことがシミュレーション の解析手法としての機能を特徵づけ，新しい分野の開 発において有効な手段を提供することになっているわ けである2て4，すなわち，表現が一般的になるが，フ ライトシミンレーションが模擬の対象とする “実事象 の飛行”という枠の中に，実際の飛行のなりゆきだけ でなく，実際に起りえない“なりゆき”をも自由に含 めることができるということである．例えば、シミュ レーションを行うとき，その目的に応じて，実事象の 飛行の中に次のようなものを考えることがてきる.

・特殊なトラブルの生成

- 連続事象の順序の変換あるいは部分生成

- 抽象的に限定された事象の生成

・時間の長さの自由な設定

具体的な例を揭げてみると，短時間における各種の トラブルの発生、離陸フェースぬきの着陸フェースの みの実現, 綎の運動のみの模擬，長時間にわたる飛行 事象の短時間での再現といった，非常に効率的な試駼 を行うことができるわけである．そこてこのようなフ ライトシミュレーションを実現させる方法として現在 どのようなものがあるか，またその特徴はどこにある のかを整理したものが第 2 図である.この図にそって もう少し詳しく考えてみることにする。

フライトシミュレーションは第1図に示したように 実事象の飛行を数学モデルを通して実現するのか. あ るいは物理モデルを通して実現するのかによって2つ に分けられる.まず数学モデルによる場合，模揪飛行 の実現は計算機という環境の中で行われるが，その結 
果を利用する人間とのインターフェースのとり方は多 样てある.すなわち目的, 内容によって, 計算機の中 て求められる莗動をもとに様々な形て模振飛行を表現 する必要があるわけて，それに応して様々なシミュレ 一タが考えられている。

第 1 はディジタル・シミニレーションあるいは数学 シミュレーションと呼ばれるもので，計算機で得られ た桔果をグラフィックディスプレイやラインプリンタ など10機器に出力させることで分に目的を達する ことがてきるものである.シミュレーション研究の大 半はこの手法によるものといってよいかもしれない.

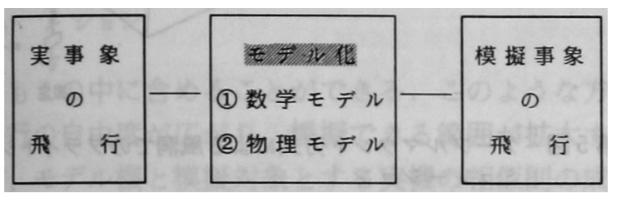

第1図 フライトシミュレーション

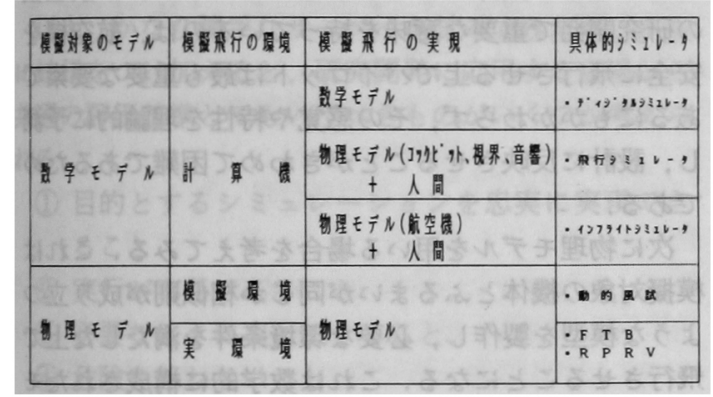

第 2 図 フライトシミュレーションの分類
次は数学モテルを用いて計算機上で一旦実現された 飛行をさらに物理モデルを用いて表現するもので、こ の物理モデルとしてコックピットを用いたものが，通 常“フライトシミュレータ”としてよく知られている ものである. 現在, 航空機の研究開発及びパイロット の訓練にとって欠かせないものである，この概念図を 簡単に示すと第 3 図のようになる。模擬対象である機 体の数学モデル，及び大気など環境モデルを用いて， 計算機上で求められたパイロットによる操航応答をも とに、視界、モーションの情報がコックピットに送ら れ，搭乗したパイロットの体感として，模稌飛行が実 現されることになる。もちろん地上に設置されたコッ クピットは運動の範囲が限られるわけて，特に並進運 動や加速度運動を継続できる時間は極端に限定され る.それでもコックピットに搭乗している人間にはあ たかも飛行運動が継続しているかのような感覚を与え ることができる゙）フライトシミュレーションでは模 擬しようとする対象がモテルを通して等価的な事象と して夷現されるわけであるが，ただそれが人間を通し て行かれる場合には，感覚の上で等価であればよいわ けで，必ずしも物理的に等価である必要はないことに なる。

一方，実際に航空機を飛ばして行うインフライトシ ミュレーションでは，模擬飛行を実現するコックピッ トの動ける範囲が大空の中に拡大される. 第 4 図にイ ンフライトシミュレーションの概念図を示した. パイ ロットの操舵に応じて，模擬対象機に発生する運動を その数学モデから求め，同様の運動を母機（模程を

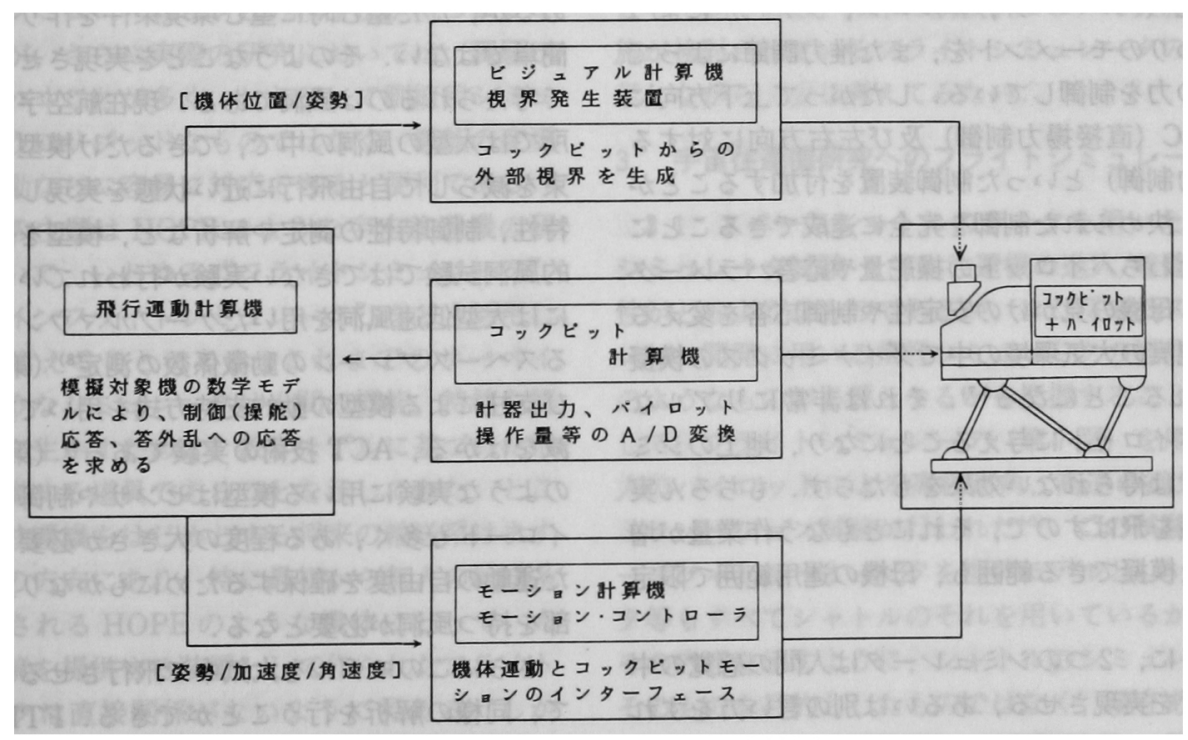

第3図 フライトシミュレータの概念図 


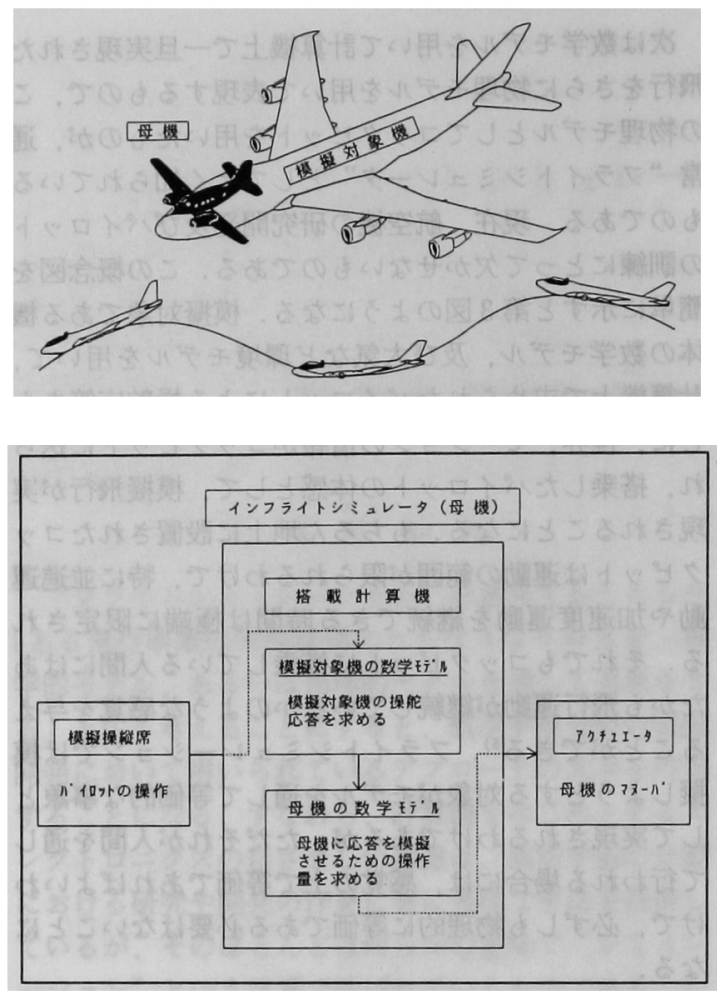

第 4 図 インフライトシミュレータの概念図

実現させる機体）に引き起すように組立られた制御則 に従って，母機の制御量が決められる。ところで，も し機体の 3 軸方向の力及び 3 軸まわりのモーメントを 自由に調節することができれば，剛体と考えた航空機 の任意の運動は実現できるはずである．通常の航空機 は空力 3 舵（エレベータ，エルロン，ラダー）によっ て3軸まわりのモーメントを，また推力調節によって 前後方向の力を制御している.したがって上下方向に 対する DLC (直接揚力制御) 及び左右方向に対する $\mathrm{SFC}$ (横力制御) といった制御装置を付加することが できれば，決められた制御を完全に達成できることに なる，すなわちパイロットの操舵量や応答パラメータ を修正し、母機の見かけの安定性や制御応答を変える ことで，現実の大気環境の中でダイナミックスの模擬 が実現されることになる.7) それは非常にリアルな 緊張感をパイロットに与えることになり，地上のシミ ュレータでは得られない効果をもたらすももちろん実 際に航空機を飛ばすので，それにともなう作業量が増 大し，また模擬できる轮囲も，母機の運用範囲で限定 はされる。

このように，2つのシミェレータは人間の感覚の中 で模擬飛行を実現させる，あるいは別の言い方をすれ ばパイロットに飛行環境の一部を提供する装置という

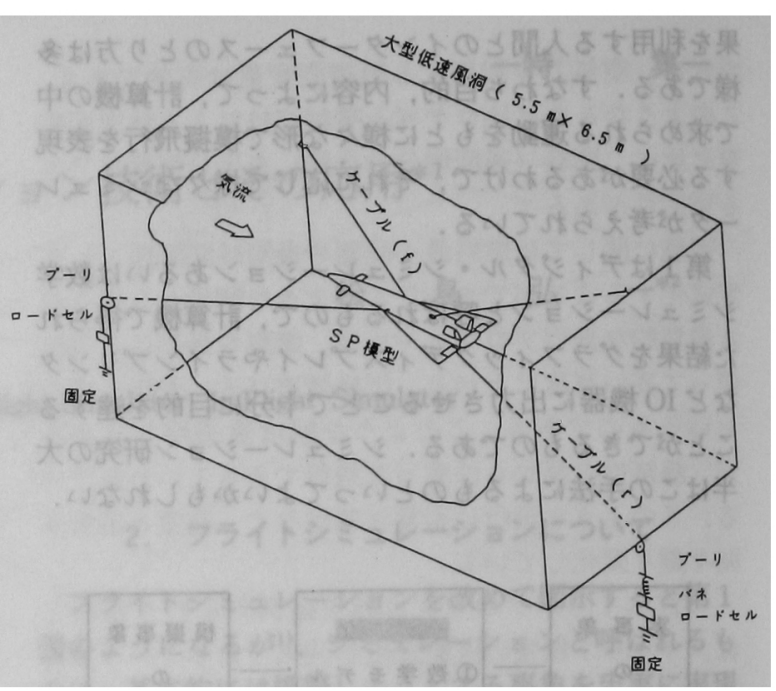

第 5 図 ケーフルマウント方式による風洞てのフライトシ ミュレーション

ことになる．実際にこのようなシミュレータが航空機 の研究開発で重要な意味を持っているのは，航空機を 安全に飛行させる上でパイロットは最も重要な要素で あるにもかかわらず，その感覚や特性を理論的に予湘 し、設計に反映させることがきわめて困難てあるため である。

次に物理モテルを用いる場合を考えてみる。これは 模擬対象の機体とふるまいが同じか相似則が成り立つ ような模型を製作し，必要な環境条件を満たした上て 飛行させることになる。これは数学的に構成されたモ デルではわからない，新しい現象を見つける可能性も あるが、ただ望む時に望む環境条件を作り出すことは 簡単ではない，そのようなことを実現させる装置とし て考えられるのは風洞である. 現在航空宇宙技術研究 所では大型の風洞の中で，できるだけ模型に対する拘 束を隇らして自由飛行に近い状態を実現し，動的空力 特性、制御特性の測定や解析など，模型を固定した静 的風洞試験ではできない実験が行われている，具体的 には大型低速風洞を用いたケーブルマウント方式によ るスペースプレーンの動微係数の測定")(第 5 図)，及 び支柱による模型の動的支持方式を用いて突風荷重軽 滅をはかる，ACT 技術の実験である》(第 6 図).こ のような実験に用いる模型はセンサや制御機器などぺ イロードも多く，ある程度の大きさが必要であり，ま た運動の自由度を確保するためにもかなり大きな測定 部を持つ風洞が必要となる。

さらにこのモデルを大気中で飛行させることによっ て、同様の解析を行うことができる.FTBや研究用 $\mathrm{RPV}$ ，さらにある特定のミッションを持った実験機 


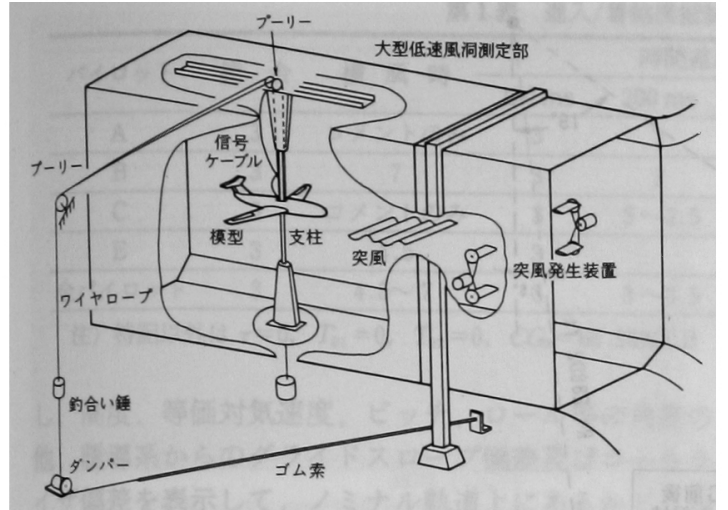

第6図 支柱支持方式によろ風洞てのフライトシミュレー ション

などもこの中に含めることができる．このような方法 は飛行の自由度が広がり，模擬できる範囲が拡大する 一方，モデル機と模擬対象とする実機の相似則の成立 性や環境条件の正確な測定など, 結果の解析を行う上 て研究すべき課題も多く持っている。

以上，かなり勝手なサーべイを試みてみたが，さら に蛇足をつけ加えると，研究開発に応用する立場から 共通の評価基準とてもいうべきものがいくつか考えら 几る.

(1) 目的とするシミュレーションを忠実に実現でき ること.

(2) 実行が容易てあること.

(3)必要なときに実行できること.

(4) 危険を伴わないこと.

(5) 低コストであること.

これらはシミュレーションという手法が持つ重要な 特徵であるが、さらに実際の研究においては，課題が 常に変っていくことが多く，したがって訓練用シミュ レータのようにリジッドなものではなく，機能の変更 や改修、移動などに容易に対応できると便利である。

さて本稿の主題は HOPEのような宇宙往還機の研 究開発において、いわゆる“フライトシミュレータ”。 あるいは“インフライトシミュレータ”をどう活用し ていくかを考えることにある.これまでのサーべイ て、このようなシミュレータは人間の機能，特性を解 析し、設計に生かすために，数学モデルに基づいた飛 行嘼境を提供する道具であることを示してきた。 とこ ろが，宇宙往還機をはじめとする将来の輸送系はます ます自娌化の方向にあり，特に最初から無人の輸送系 として設計される HOPEのような機体にとって，人 間に飛行謤境を提供する装置として作られたフライト シミュレータは直接関係がないように見える.しか し，無人機といえども設計するのは人間であり，設計

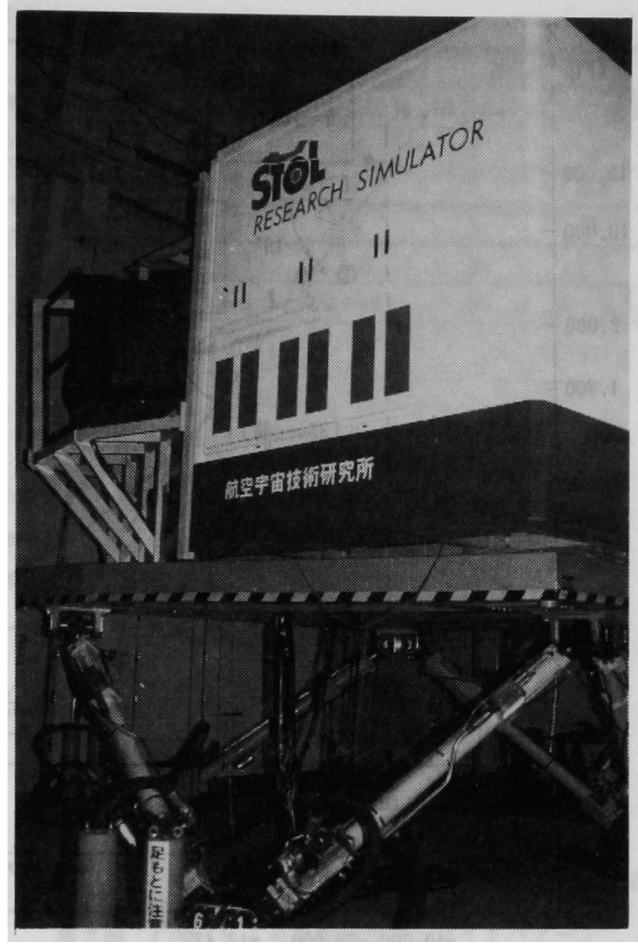

第 7図 NAL フライトシミュレータ

者には知識だけでなく，ある範囲の体験，あるいは経 験の蓄積に董付けられた直感力といったものが要求さ れるものである. 宇宙往還機のようにその飛行過程を 簡単に経験することが困難な場合には，フライトシミ ニレー夕は大変に有効な道具になりうると考えられ る.また従来のシミュレータの活用範囲を搪張するこ とも可能である，以下に航技研において実施または実 施が検討されているフライトシミニレータの活用例を 示しながら，少し考えてみたい。

3. 宇宙往逼機研究へのフライトシミュレータの応用

3.1 スペースシャトルのデータを用いたフライト シミュレータ試験 宇宙往還機の進入/着陸時の飛行 性がどのようなものであるか，また将来のスペースプ レーン開発に用いる飛行シミュレータの機能としてど のようなものが必要となるかを把暒することを目標と して、フライトシミュレータ（第 7図）を用いて，5 人のパイロットによる高経路角, 高速の進入/着陸シ ミュレーション試験が行われた ${ }^{10)}$ 。この試験ではスペ ースシャトル・オービタを機体モデルとし, 空力デー 夕等もすへでャトルのそれを用いているが. 以下に その内容を示すように, シャトルのシミュレーション そのものを目的としたものではなく，現在あるフライ トシミュレータの機能をフルに活用して，将来のスペ 


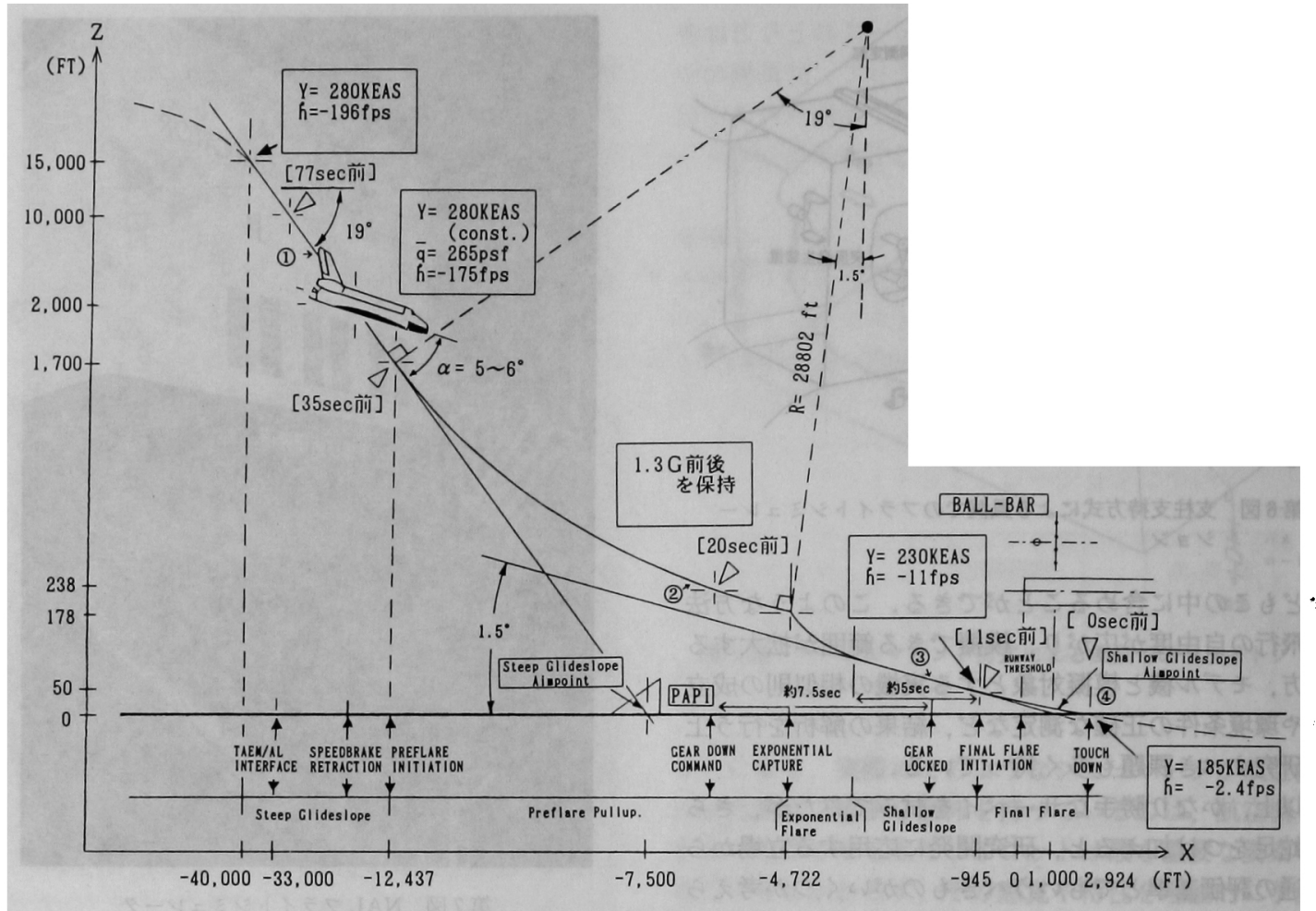

第 8 図 進入/着陸におけるフライトプロファイル

ースプレーンで予想される我行を体験してみようとい うものである.まずどのような飛行プロファイルを想 定したかというところから始めて，シミュレーション を実行するためのいくつかの仕掛，試験の内容，そし てどのような結果が得られたかという順で紹介した い.

3.1 .1 飛行プロファイル 今回模擬を行った進 入/着陸フェースは第 8 図に示したように次の 4 つの サブフェーズからなっている。

(1) スティーブ・グライドスロープ:経路角一定 (約一19度) で滑空降下を行う。パイロットは滑走路

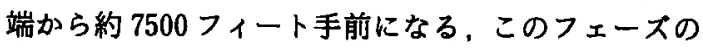
地上補捉点（Aim Point）に設置された PAPI（後述） によって経路角維持を行う.

(2) プリフレア: 高度 2000 フィート前後で開始， 垂直加速度を約 $1.3 \mathrm{G}$ に保った円弧を描いた後，指数 関数的に次のサブフェーズにのるよう引起こしを行 う.

(3) シャロウ・グライドスロープ：経路角を一定 （約一1.5 度）に維持する滑空降下. 滑走路端を越えて 1000 フィート地点の地上補捉点に設置されたボール・ バー（後述）が経路角維持の指標となる.
(4) ファイナル・フレア: 高度約 50 フィートで開 始. タッチダウン時の沈下率が 6 フィート/秒(脚の設 計値）以内となるように経路及び姿愬の制御を行う.

機体モデルとして用いたオービタはエレボン; ラダ 一、ボディラップ及びスピードブレーキの空力 4 觗 とRCS を用いるが，今回の試験では RCS は用いず， ボディフラップは高度及び速度の関数として制御系に あらかじめ設定されたスケジュールに従って，またス ピードブレーキはエネルギー・コントロールの役割を 果たすよう速度制御系によって駆動される．したがっ てパイロットはエレボン及びラダーを操作して；機体 を制御することになる。

3.1 .2 我行シミュレータシステム コックピット は計器取り付け位置とサイドスティックによる操倇が 行えるように改修され，また垂直加速度計は操轿時に 見やすいように空枠位置に取り付けられた．着陸時の 外部視界として長さ $5000 \mathrm{~m}$, 幅 $100 \mathrm{~m}$ の滑走路を持 つスペースプレーン空港を作成し，また地上援助装置 として，グライドスローブにおける経路角維持の指標 とする PAPI (精密進入経路指示装置、第 9 図) とボー ル・バー（第 10 図）を模擬視界に組込んている，さら に，疑似 HUD (ヘッドアップディスプレイ) を作成 
第 1 表 進入/着陸模撮試験のパイロットレーティング

\begin{tabular}{|c|c|c|c|c|c|c|c|c|c|c|}
\hline \multirow{2}{*}{ パイロサr } & \multirow{2}{*}{ 䊒 } & \multirow{2}{*}{ 横 風 時 } & \multicolumn{4}{|c|}{ 時間暒れ（z) } & \multicolumn{2}{|c|}{ リードラダ $\left(T_{01}, T_{02}\right)$} & \multicolumn{2}{|c|}{ 重心位䨵 } \\
\hline & & & $100 \mathrm{~ms}$ & $200 \mathrm{~ms}$ & $300 \mathrm{~ms}$ & $500 \mathrm{~ms}$ & $(0.5,0.9)$ & $(0.5,0.1)$ & $65 \% \mathrm{LB}$ & $67.5 \%$ LB \\
\hline A & 3 & コメントのみ & 3 & 3 & 3.5 & 4 & 3 & 2 & 3 & 3 \\
\hline B & 3 & 7 & 3 & 3 & 3 & $4 \sim 4.5$ & 3 & 4 & 3 & 3.5 \\
\hline $\mathrm{C}$ & 3 & コメントのみ & 3 & $3 \sim 3.5$ & 4 & $4 \sim 5$ & 3 & 3 & 3 & 3 \\
\hline $\mathbf{E}$ & 3 & 4.5 & 3 & & 3.5 & $4 \sim 5$ & 3.5 & 3.5 & 3 & 3.5 \\
\hline 全パイロット & 3 & $4.5 \sim 7$ & 3 & $3 \sim 3.5$ & $3 \sim 4$ & $4 \sim 5$ & $3 \sim 3.5$ & $2 \sim 4$ & 3 & $3 \sim 3.5$ \\
\hline
\end{tabular}

注）特記以外は $\tau=0, T_{01}=0, T_{02}=0, C G_{x}=66.26 \% \mathrm{LB}$

し，高度，等価対気速度，ピッチ，ロール等の角度の 他, 誘導系からのグライドスロープ偏差及びローカラ イサ㸝差を表示して，ノミナル軌道上にあるかどうか を判断する飛行情報をパイロットに対して提示するよ うにした。モーション・システムは 6 軸共䣸形のもの てあるが, 今回の試験ではその機能の限界まで作動さ せろ結果になった。

3.1.3 試要 次の 3 つの項目についての評価 試埌が行われた。

（1）シミュレー夕機能評価試験：装置の操棁席関 保、コントロール・スティック，視界等，今回作成し たシミェレータ・システムのパイロットによる評価.

（2）進入/着陸模捦試験：前述の飛行プロファイ ルに沿うシミュレーションの実施と、クーパ・ハー パ・レーティング，飛行経路とノミナル軌道との偏差， 及ひパィロット・ワークロード（サイドスティック操 作積分量）による評洒．なお評価パラメータとして横 圆 (20 kt) の有無、操舵入力から出力舵面までの信号 の時間遅れ，リードラグ，機体重心位置を考えた。

(3) HQDT (Handling Quality During Tracking)試検：情密追尾方式による更行性評価方法で，パ イロットは自機前方を一定距離で飛行するターゲット に乘行を合わせるように操轱する。評価はターゲット とボアサイト間の誤差及びサイドスティック操作量に より行い，評価パラメータとして時間遅れ，リードラ ク。機体重心位置を考えた。

3.1.4 得られた桔果この試験におけるパイロッ ト・レーティング及びパイロット・コメントの一部を 第1〜3表に示す. 結果を簡単に要約することは難し けが，無動力での進入/着陸は一般の航空機と同程度 (レヘル 1)の操揵特性が得られ，着陸パスも，その1 甽を第 11 図に示したように，ノミナルとの差が少な かった。ただ $20 \mathrm{kt}$ の横風時の着陸はかなり難しく， また時間暒れの許容値は 200〜300 ms の間にあると 思かれる.それに対し HQDT 試験の場合には時間遅 れの許容值が 100〜200 msになっているが。これは 早い㨐伦が必要となるためと考えられる．また現状の ようなシミュレータ装置てあっても極超音速形態機の

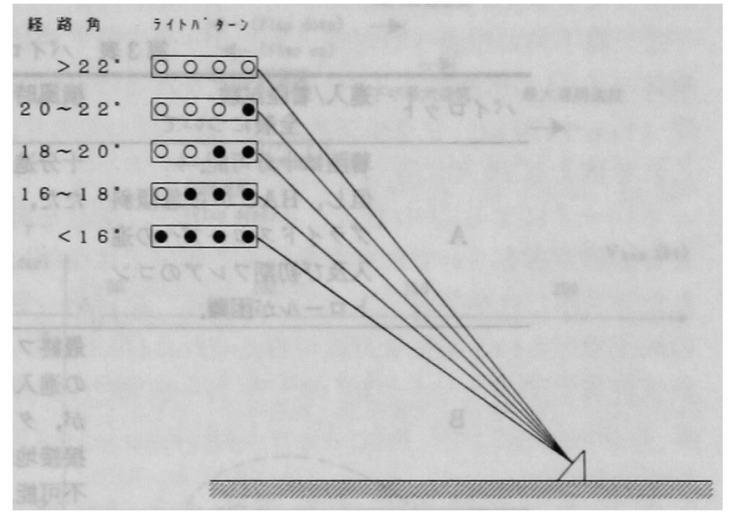

第 9 図PAPIによる経路角指示のライトパターン

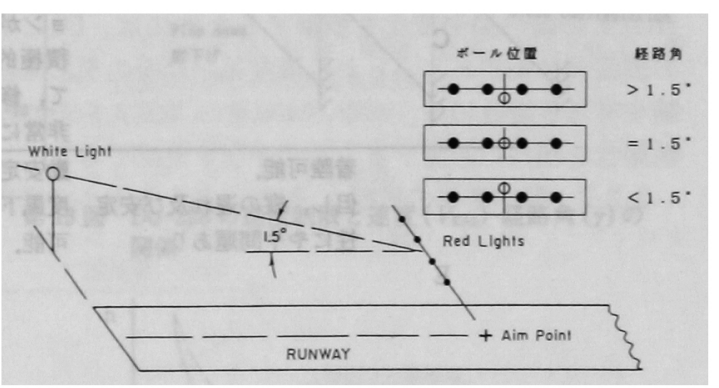

第 10 図 ボール・バーによる経路角指示のパターン

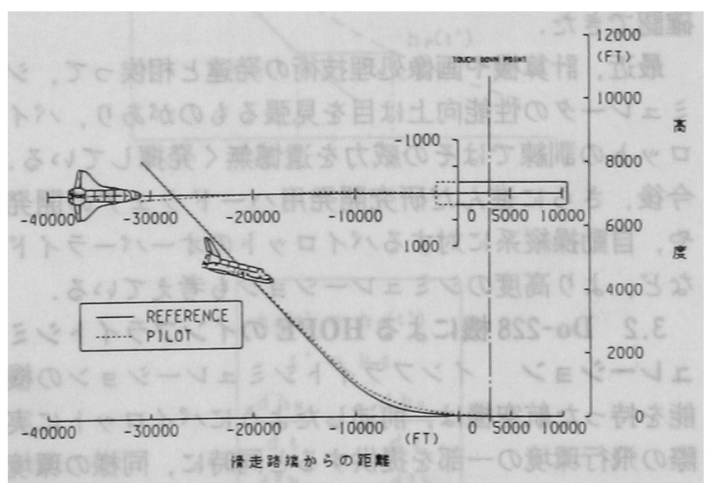

第11図 シミュレーションによる着陸パス軌跡の例 
第 2 表 HQDT 試験のパイロットレーティング

\begin{tabular}{|c|c|c|c|c|c|c|c|c|c|}
\hline \multirow{2}{*}{ パイロット } & \multirow{2}{*}{ 総 } & \multicolumn{4}{|c|}{ 時間運れ（x) } & \multicolumn{2}{|c|}{ リードラグ $\left(T_{01}, T_{02}\right)$} & \multicolumn{2}{|c|}{ 重心位祭 } \\
\hline & & $100 \mathrm{~ms}$ & $200 \mathrm{~ms}$ & $300 \mathrm{~ms}$ & $500 \mathrm{~ms}$ & $(0.5,0.9)$ & $(0.5,0.1)$ & $65 \% \mathrm{LB}$ & $67.5 \% \mathrm{LB}$ \\
\hline $\mathrm{A}$ & 3 & 3 & 3 & $5 \sim 6$ & 7 & $2 \sim 3$ & 2 & 3 & 3 \\
\hline B & 4 & 3.5 & 3 & 4.5 & 5 & 3 & 4.5 & 3.5 & 3 \\
\hline $\mathrm{C}$ & 3 & 3 & $3 \sim 3.5$ & 4 & 7 & 3 & 3 & 3 & 3 \\
\hline $\mathrm{E}$ & 3.5 & 3.5 & $3.5 \sim 4$ & 4 & 4 & 3 & 3 & 3 & 3.5 \\
\hline 全パイロット & $3 \sim 4$ & $3 \sim 3.5$ & $3.5 \sim 4.5$ & $4 \sim 6$ & $4 \sim 7$ & $2 \sim 3$ & $2 \sim 4.5$ & $3 \sim 3.5$ & $3 \sim 3.5$ \\
\hline
\end{tabular}

注) 特記以外住 $\tau=0, T_{01}=0, T_{02}=0, C G_{x}=66.26 \% \mathrm{LB}$

第 3 表 パイロットコメントの例

\begin{tabular}{|c|c|c|c|}
\hline パイロット & $\begin{array}{c}\text { 進入/著陸試験 } \\
\text { 全般について }\end{array}$ & $\begin{array}{r}\text { 僙風時の進入/著陸 } \\
\text { について }\end{array}$ & $\begin{array}{l}\text { HQDT 試験 } \\
\text { 全般について }\end{array}$ \\
\hline A & $\begin{array}{l}\text { 着陸は十分可能. } \\
\text { 但し, HAC から急傾斜 } \\
\text { グライドスロープへの進 } \\
\text { 入及び初期フレフのコン } \\
\text { トロールが困奞. }\end{array}$ & $\begin{array}{l}\text { 十分進入はできる. } \\
\text { ただ, 慣れが必要. }\end{array}$ & $\begin{array}{l}\text { バンクインデックスは HUD } \\
\text { の上側にあった方がよい. }\end{array}$ \\
\hline
\end{tabular}

\begin{tabular}{|c|c|c|c|}
\hline B & & $\begin{array}{l}\text { 最終フレアまでの滑走路へ } \\
\text { の進入コースは制御できる } \\
\text { が,タッチダウン直前の直 } \\
\text { 接接地が飛行制限值内では } \\
\text { 不可能. }\end{array}$ & $\begin{array}{l}\text { 機体通功の追従性が㷂い. } \\
\text { ボフサイト形状がよくないた } \\
\text { め,バンク角をターゲットに } \\
\text { 合わせるのが困難である. }\end{array}$ \\
\hline C & $\begin{array}{l}\text { 特に困難な点なく著陸は } \\
\text { 可能. }\end{array}$ & $\begin{array}{l}\text { オンコース上から着陸する } \\
\text { のは可能だが，デヒエーシ } \\
\text { ョンがある状態からこれを } \\
\text { 糟極的にコントロールし } \\
\text { て, 修正し, 着陸するのは } \\
\text { 非常に困難である. }\end{array}$ & \\
\hline $\mathrm{E}$ & $\begin{array}{l}\text { 着陸可能. } \\
\text { 但し、粒の幄れ及び安定 } \\
\text { 性にゃゃ問題あり. }\end{array}$ & $\begin{array}{l}\text { 䖝安定が悪くなる感じで一 } \\
\text { 度風下に流されると修正不 } \\
\text { 可能. }\end{array}$ & $\begin{array}{l}\text { カを入れすぎるとオーバーコ } \\
\text { ントロールとなる. } \\
\text { バンク角がターゲットに一致 } \\
\text { するとー誎コントロールとな } \\
\text { り, トラッキンダは容易にな } \\
\text { る. } \\
\text { ターゲット形状がよくない. }\end{array}$ \\
\hline
\end{tabular}

進入/着陸に関する部分評価は十分可能であることも 確認できた。

最近, 計算機や画像処理技術の発達と相俟って, シ ミュレータの性能向上は目を見張るものがあり．パイ ロットの訓練ではその威力を遗㙳無く発揮している. 今後,さらに進んだ研究開発用ハードウェアの開発 や，自動操繸系に対するパイロットのオーバーライド など，より高度のシミュレーションも考えている。

3.2 Do-228 機による HOPE のインフライトシミ ュレーション インフライトシミュレーションの機 能を持った航空機は，前述したようにパイロットに実 際の飛行環境の一部を提供すると同時に，同様の環境 を例えばセンサや電子機器，あるいはHOPEの自動 制御システムといった機械にも提供することができ る.これはインフライトシミュレータが模擬対象のダ
イナミックス，あるいはその一部を忠実に模擬してい るためである. しかしインフライトシミュレーション の可能な範囲は母機の持つ性能によって当然制約され る. したがって HOPEの飛行というものを模擬対象 としたとき，現在ある母機でその運動をどこまで模擬 できるのかを明確にすることがまず大切である．現在 航技研の保有するドルニエ機（Do-228）(第 12 図）を 母機としたときの理論的検討を行っているのて，その 概要を紹介したい(1).

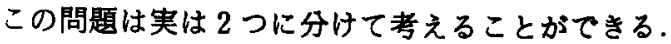
1 つは釣り合い飛行状態の模擬がどこまでてきるか， もう 1 つは釣り合い状態からの動的応答の模擬をどこ までできるかという問題である.

3.2 .1 验り合い状態のシミュレーション 機体に 作用する空気力が一定になるような刑行を釣り合い状 


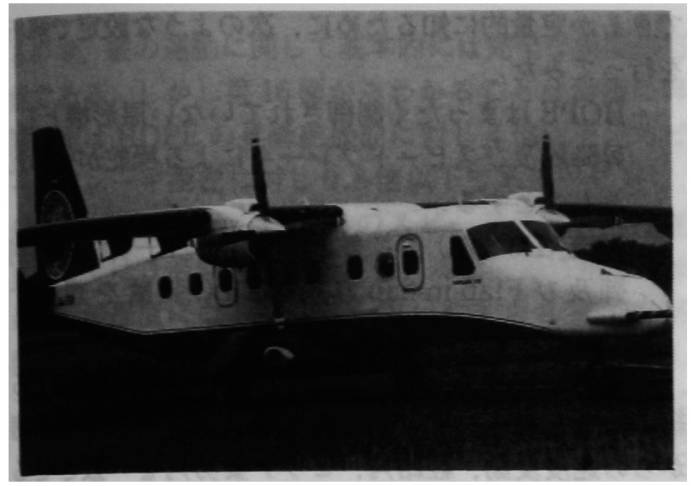

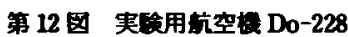

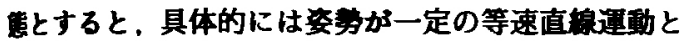
か、旅回やきりもみなどのような鈴直軸を回転べクト ルとする等角速度運動であるが，特に進入/着陸フェ ースにおいて，MLSをはじめとする HOPE の着陸 法系の試験や自動着陸実験を行う上で，速度と降下 角をパラメータとする等速直楾運動の釣り合い状等の シミュレーションがどこまでできるかは大きな問題て ある.

第 4 表にDo-228 機と想定した HOPE の基本パラ メー夕の比筊を、また第 13 図にDo-228の速度制限 を示した.シミュレーションで使用できるのは最小操 篗速度以上，最大運用速度以下と考えられ，着陸進入 速度で $200 \mathrm{kt}$ を超える HOPEに対し，速度に関し て佥り合い状意を達成することは不可能である。

一方，降下角について考えてみると，第13図に示 されたDo-228 の速度と降下角の関係では，いずれの 場合も $-9^{\circ}$ 程度が最大となっている。 それに対し HOPE は $-20^{\circ}$ 以上と考えられ，経路角に関しても シミンレーションは困難と思われる.このように HOPEの矣り合い状隹のシミュレーションをDo-228 て行うことは難しいとしても，着陸航法系の試賖等を 考えた場合，何らかの模擬条件の楥和を行って，かな 実用的な試験を考えることはできそうである．例え 隹入速度、降下角，姿势の不一致といった現象の原 因てある速度レンジの相違，捍抗比 $(L / D)$ の相違，空 力知保数 $\left(C_{L e,}, C_{y \mathrm{~A}}\right.$ など)の相違といった問題に現実的 に対趃する方策として以下のようなことが考えられ 3.

(1) 速度レンジの相戛への対処：進入/着陸フェー オのシミュレーションにおいて，長さのスケールを一 要させ，HOPEに对する母機の時間スケールの比を 1封kにとる。例えば航法系フィル夕の試駼を行う ことを考えてみると，母機上のセンサ出力をフィルタ 㗭入力する祭に次の対店が考えられる (第 14 図).
第 4 表 Do-228 と HOPE の基本パラメータ

\begin{tabular}{|c|c|c|}
\hline & Do-228 & HOPE(仮定) \\
\hline 重 兵 (ton) & 5.7 & 7.5 \\
\hline 面磷 (m & 32 & 30 \\
\hline 偪 （m) & 17 & 6.6 \\
\hline アスペクト比 & 9 & 1.4 \\
\hline 面荷重 $\left(\mathrm{kg} / \mathrm{m}^{2}\right)$ & 180 & 250 \\
\hline 首陸進入畽度 （kt） & 90 & 240 \\
\hline 盖陸進入娃路角 （deg） & 3 & 20 \\
\hline
\end{tabular}
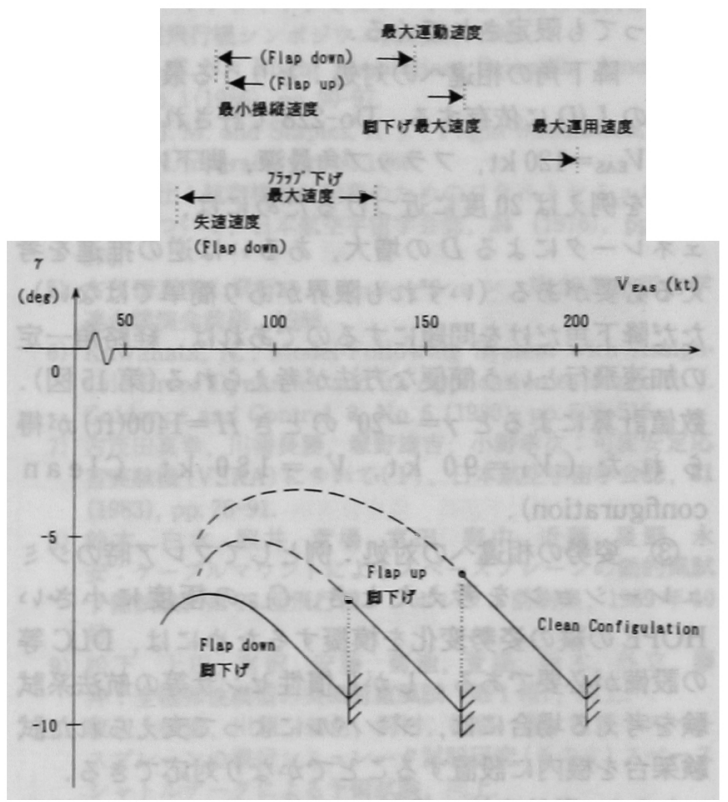

第 13 园 Do-228 の速度制限と速度 $\left(V_{\text {EAS }}\right.$ )-目路角 $(\gamma)$ の 関保
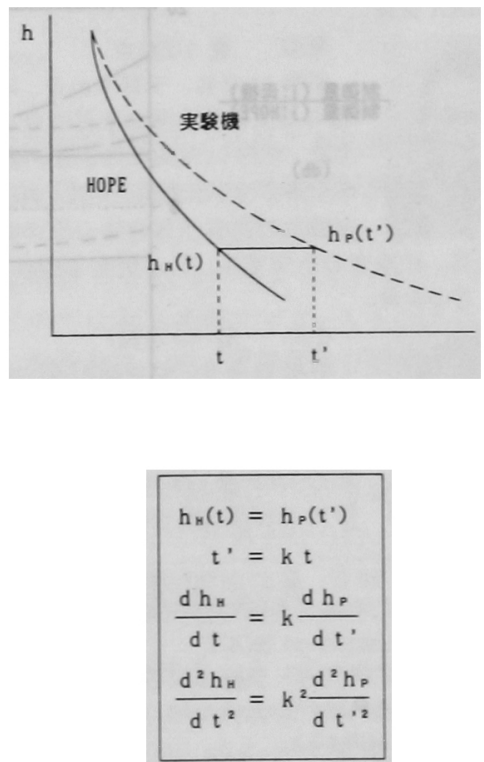

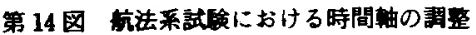


位置/姿勢角センサの出力 速度/角速度センサの出力 加速度センサの出力

航法フィルタ計算機クロック周波数 航法計算での重力加速度 $g$

HOPE と実験機のアプローチ速度を比較してみる と， $k \sim 2$ となるが，上記の仮定が $k$ のどの箅囲の值 まで適用できるかは各センサのダイナミックレンジ等 によっても限定されてくる.

(2) 降下角の相蚞への対処：とりうる最大降下角は 機体の $L / D$ に依存する．Do-228で許されるのは約 9 度 ( $V_{\mathrm{EAS}}=120 \mathrm{kt}$ ，フラップ角最深，脚下げ)であり， これを例えば 20 度に近づけるためには，ドラッグジ エネレータによるDの增大，あるいは逆の推進を考 える必要がある（いずれも限界があり簡単ではない）. ただ降下角だけを問題にするのであれば，経路角一定 の加速飛行という簡便な方法が考えられる(第 15 図). 数值計算によると $\gamma=-20^{\circ}$ のとき $H=1400(\mathrm{ft})$ が得 られた $\left(V_{1}=90 \mathrm{kt}, V_{2}=180 \mathrm{kt}, C l e a n\right.$ configuration).

(3) 姿勢の相違への対処 : 例としてフレア時のシミ ュレーションを考えたとき， $C_{\mathrm{L} a}$ の極度に小きい HOPE の縦の姿势変化を模擬するためには, DLC 等 の設備が必要である.しかし慣性センサ等の航法系試 験を考える場合には，ジンバルによって支えられた試 験架台を機内に設置することでかなり対応できる.

\section{2 .2 功的応答の模擬 動的応答をどこまで模擬}

できるか定量的に知るために，次のような設定て解析 を行ってみた。

・HOPEはまったく制御されていない原形機とし， 昇降舵及びスピードブレーキによる操舵が行かれ るものとする。

・母機 (Do-228) の操舵としてエレベータ，推力制 御及び Flap-in-flap 方式の DLC装錮を想定す る.

以上の条件のもとて，模程対象の HOPEに対する 綐のシミュレーション制御系を設計し，釣り合い作点 からの速度変動, 経路角, ピッチ姿等角を一致きせる シミュレーションを行うとき，母機に必要とされる操 舵量を周波数領域て調へてみた (第 16 図).

この場合， 3 自由度全てをカバーする制御装置があ

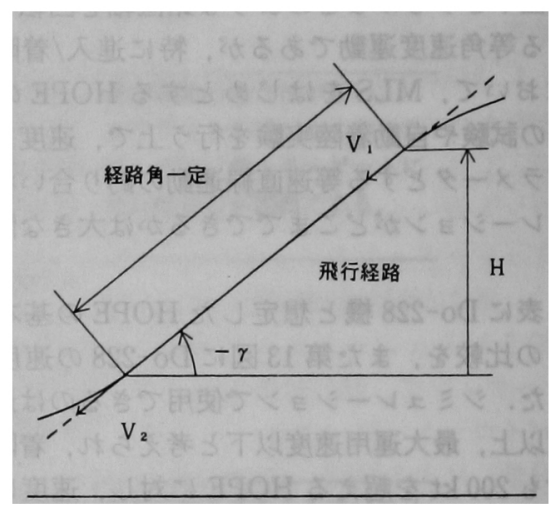

第 15 図 航法系試駼における高降下角の達成
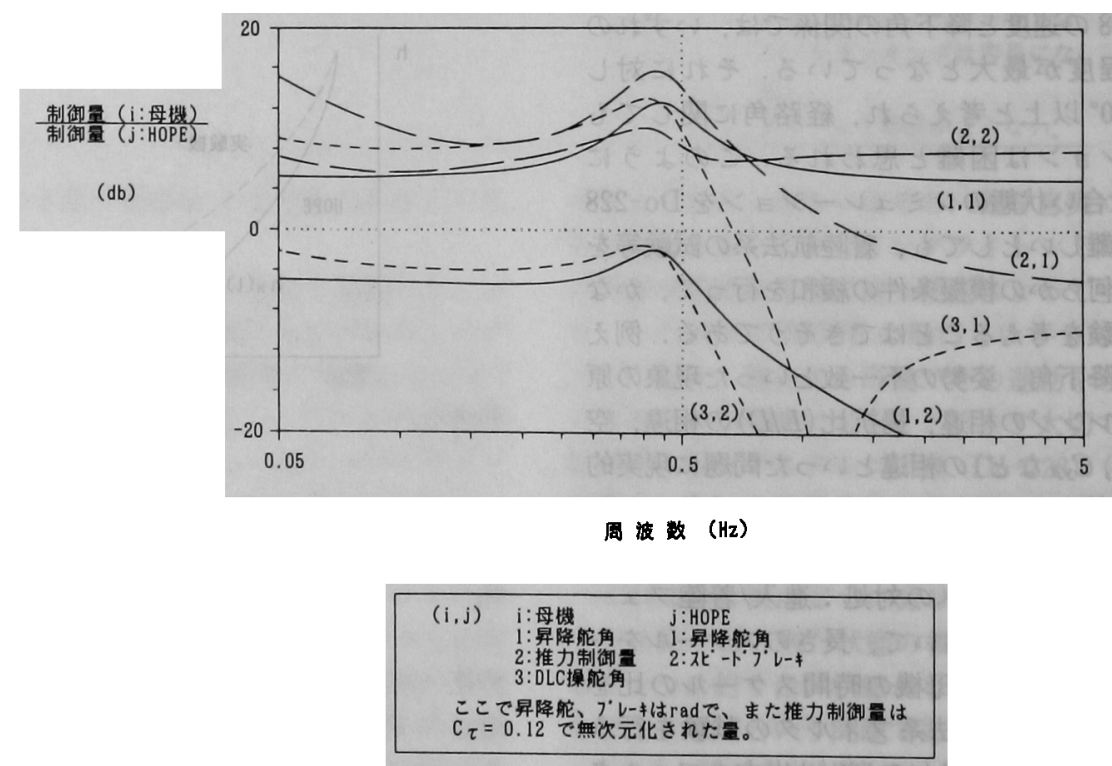

第 16 図 インフライトシミュレータの操舵量の周波数応答 
るのて，䌅の運動に関して基本的には完全な模擬が可 能てある.しかし第 16 図からわかることは母機の昇 降倇角は HOPE の昇降舵㨐舵に対し 4 倍以下，スピ ードブレーキ操舵に対し 0.8 倍以下であるのに対し， 母機のパワ制御は，HOPEのスピードブレーキ操舵 に対しては 3倍以下であるが．昇降舵制御に対しては 最大 6 倍程度になる。一方，DLC 操舵角は HOPE 昇 降拕に対して 4 倍以下，スピードブレーキ操舵に対し ては 0.8 倍以下となっている．したがって推力制御に よる前後方向の力の制御が最もクリティカルになると 思われる。

いずれにしてもHOPEの飛行特性は，縦の静安定 が負，また横方向ではダッチロールモードが不安定と なっており、空力舵面のフィードバック制御による安 定化が必要となる。もしこの制御が行われれば機体の 運動は小さく抑えられるはずて，したがってそれを模 㩧する場合には，母機側の操舵能力に対して，より緩 い条件を与えることになる．今後はフィードバック制 御系を含めた HOPEの運動を対象にしたDo-228 機 の我行模擬範囲の検討を行っていく必要がある.

\section{4.あとがき}

とにかく宇宙往還機のような新しい機体の開発にお いて，フライトシミュレータに限らず，必要となる試

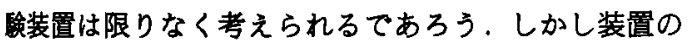
設計・製作にはコストだけでなく，時間も非常にかか るものである. 本当に必要な装置を明確にする上で も，現在ある設備を最大限に活用して，少しでも基礎 的テータを蓄䅡することが当面の急務であるう.
最後に本稿をまとめるにあたつて，航空宇宙技術研 究所堀川勇壮特別研究官 (故人), 制御部渡辺碩室長及 び飛行実験部宮沢与和主任研究官に討論や資料の提供 を通して大変お世話になったことを記して謝意とした い.

\section{参考文献}

1) 松島弘一: フライトシミュレーション技術の現状と役割, 第 27 回飛行機シンポジウム前刷集，1989.

2) Haber, R. N.: Flight Simulation, Scientific American, 255, No. 1(1986), pp. 90-97.

3) Rolfe, J. M. and Staples, K. J. : Flight Simulation, Cambridge University Press, 1986.

4）堀川勇壮：航空機設計開発のためのフライトシミュレータ 試験について，日本航空宇宙学会誌，24 (1976)，pp. 360370.

5）古茂田真幸：飛行のシミェレーション, 第 38 回応用力学 連合譜演会前刷, 1988 .

6) Kawahata, N.: Model-Following System with Assignable Error Dynamics and its Application to Aircraft, J. Guidance and Control, 3, No. 6 (1980), pp. 508-516.

7）古茂田真幸，川幡舆勝，塚野雄吉，小野孝次：可変安定応 答夷験機 (VSRA) について(I)，日本航空宇宙学会誌. 31 (1983), pp. 75-91.

8）鈴木，白水，照井，营場，室田，野中，近藤，星野、永 安：ケープルマウントによるスペースプレーンの㽖的風試 予備試験，第 27 回飛行機シンポジウム前刷集，1989 年 10 月.

9）松下，上田，宮沢，安藤，获池，苜場，鉿木，外立。藤 井：全機弾性模型の突風荷重風試 (第 1 報)，同上.

10）洨辺，柳原，川原，若色，河村，福留，僼，钽野：スペー スプレーンの飛行シミュレータ試験研究（その1）スペース シャトルデータによる予備試臨，同上.

11）宮沢与和，内田忠夫，松島弘一：インフライトシミュレー 夕によるHOPEの飛行実酸の検討, HOPE ワークショッ プ霓演集， 1989. 